\title{
PTEN wt Allele
}

National Cancer Institute

\section{Source}

National Cancer Institute. PTEN wt Allele. NCI Thesaurus. Code C52906.

Human PTEN wild type allele is located in the vicinity of $10 \mathrm{q} 23.3$ and is approximately 109 $\mathrm{kb}$ in length. This allele, which encodes phosphatidylinositol 3,4,5-trisphosphate 3phosphatase and dual-specificity protein phosphatase PTEN protein, plays a role in multiple signal transduction pathways. The wild-type allele influences cellular proliferation, survival, adhesion, migration and cell cycle progression through the modulation of the phosphorylation state of both phosphoinositides and focal adhesion kinase. Mutated forms of the gene are found in a large number of cancers. 